$\begin{array}{lll}\text { VOL. XXV APRIL, I9I5 NO. } 2 & \end{array}$

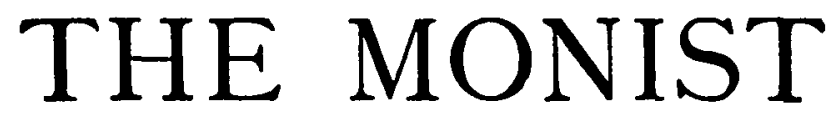

\title{
THE DISCIPLES OF JOHN AND THE ODES OF SOLOMON.
}

THE purpose of the present study is to prove that the 1 Odes of Solomon were written by one of the Disciples of John at Ephesus, not long before 55 A. D.

The great strength of the movement started by the Baptist is implied by the references to it in Josephus, ${ }^{1}$ the Gospels, the Acts and the early Fathers. ${ }^{2}$ Some scholars $^{3}$ see in the Mandaeans, otherwise known as Sabaeans or "St. John's Christians," a sect on the Persian Gulf which persisted until the nineteenth century, an offspring of the Disciples. The reverence in which they hold John's name, and the emphasis they place upon baptism, support this theory, but if it is correct the sect must have borrowed much from Christianity and other religions.

The doctrines ${ }^{4}$ of the community were those of a modified Judaism. There is every reason to suppose that its votaries clung to circumcision and the law, as did the earliest Christians. Their distinctive marks were baptism, ${ }^{5}$

${ }^{1}$ Antiquities, XVIII, 5, 2.

- Conveniently collected by W. Bauer, Das Leben Jesu im Zoitalter der meutestamentlichen Apocryphen, 1909, pp. 85-7, 101-109.

' Neander, Church History (English, 1866), I, 376; B. W. Bacon. The Story of Paul, 1904, p. 180; Encyclopedia Britonnica, s. v. "Mandaeans."

'It has been asserted that we have in the recently published Fragments of a Zadokite Work, a writing of the Disciples. See G. Margoliouth in the Athenoum, Nov. 26, 1910 and in the Expositor, Dec. 1911 and March 1912. Notwithstanding the dissent of $R$. $H$. Charles, I regard this identification as most probable.

- Perhaps borrowed from earlier Jewish sects. Josephus, De Bell. Jud., II, 8; and Test. Levi, XVI, $3 f$. 
asceticism or "fasting,"6 including probably abstinence from wine ${ }^{7}$ and disapproval of marriage, ${ }^{8}$ emphasis on "conversion," and on the Messianic hope. The asceticism of the sect is brought out by traditions about its founder. Thus Justin ${ }^{10}$ writes that he ate nothing but locusts and wild honey. Even the insects were offensive to the vegetarian principles of the Ebionites who, by the slight change of a'xoís to Exxoís reduced his fare to cakes of honey and oil." Tatian" also gave him the Old Testament diet of milk and honey.

The coming of the Messiah is the burden of John's message in the oldest source, ${ }^{13}$ and it continued to be very prominent in the teaching of his disciples later. It is certain, however, that neither John nor his disciples recognized this Messiah in Jesus. Our oldest source says nothing of a meeting between John and Jesus, but it does recount that while in prison the Baptist sent to Christ to inquire if he were really the coming one. The answer implies an affirmative, but John's reception of it is not related, and Jesus's subsequent discourse to the multitude proves that $Q$ reckoned John as a good man, indeed, but not within Christ's own circle of disciples, "the kingdom of heaven." Indeed, had the Baptists all recognized Jesus they could not have continued as a separate sect. The pains to deny the

- Mark ii. 18-22.

'Luke i. 15.

'Shown by the certification of John's virginity by Tertullian, De monogamia, 8 and Pseudo-Clemens, Virginibus, I, 6.

- This is the best translation of Merdvora. Cf. W. B. Smith, Ecce Deus, 1912 , p. 286. Further, the word is used of turning from the false to the true faith in Rev. ix. 20 and xyi. 11, and in the Martyrdom of Polycarp, IX, 2 and XI, 1. In Ecclesiasticus xliv. 16, it is used of Enoch's translation, interpreted by. Philo as a conversion to a better life, (note in Wace's edition of the Apocrypha, ad. loc.). W. W. Jäger has shown that the word was used by the Stoics of ethical conversion (Umkehrung), Göttingische Gelehrten-Anseigen, 1913, pp. 590ff.

"Dialogue with Trypho, Chap. 88.

is Eplphanius, Hoer., XXX, 13. 1895 , pp. I7f.

"Fragments of the Commentary of Ephrem Syrus on the Diatessaron,

${ }^{2} Q$, represented by Matt. iii. 5.7-12 = Luke iii. 3-9; and Matt. xi. 2-19= Luke vit 18-35. 
Messianic claims of John, and to make him point to Jesus, in the Third ${ }^{14}$ and Fourth Gospels, ${ }^{15}$ point, considering the polemic bias of both authors, to the same conclusion. When Paul converted a number of these men at Ephesus he was obliged to inform them of the name of the Messiah whose coming their master announced. ${ }^{16}$ Marcion and his fellows, in stating not only that John never recognized Jesus but that he was actually offended at him $^{17}$ as at something alien, were probably not giving the results of their Biblical researches but of their observations of the sect. In much later times the Sabaeans - spiritual descendents of the Johannites-represented Jesus as the corrupter of John's baptism. ${ }^{18}$ Many scholars, ${ }^{19}$ in fact, now recognize that the two movements were distinct, though others still persist in treating the Disciples as merely "imperfectly instructed Christians." "20

The chief support of this latter view is the verse in Acts, which tells that Apollos, a Disciple of John, "taught accurately the things concerning Jesus." As it stands, this verse is a mistake, due neither to Luke's carelessness ${ }^{23}$ nor to his poor source, ${ }^{23}$ but to the fact that Apollos's Messianic teaching was so closely similar to that of the Christians that Luke believed that it must refer to the same Christ. The reason for this similarity is not that either sect borrowed from the other, but that both drew on a large

"Harnack, Luke the Physician, 226.

"Baldensperger, Der Prolog des vierten Evangeliums, 1898; M. Dibelius, Johanues der Täufer, 1911, p. 112 ; B. W. Bacon; The Fourth Gospel in Debate and Research, 1909, p. 290.

"Acts xix. 4.

"Tertullian, Against Marcion, IV, 18; Adamantius, Dialogue, I, 26.

${ }^{10}$ Neander, Church History, (English, 1866), I, 447.

10. E., MeGiffert, Aposiolic Age, 1897, 291; O. Pfeiderer, Primitive Christianity, (English, 1909), II, 255.

* R. B. Rackham, Acts of the Apostles, 1901, pp. 340f; M. Dibelius, Johannes der Täufer, 1911, pp. $90 \mathrm{f}$.

acts xviii. 25.

- B. W. Bacon, Hibbert Jourmal, IX, 748.

- Pteiderer, loc. cit. 
body of Messianic ideas current in the Jewish writings, particularly the Apocrypha and Pseudepigrapha. Apollos and the evangelists alike based on this source their Messianic doctrine, the only difference being that the Christians applied it all to a definite person, while the Disciples did not. ${ }^{24}$

The best known community of Johannites was that founded by Apollos at Ephesus. Paul came to this great city after being driven out of Corinth, probably in the year 52. Not long after his arrival he made a journey inrough Antioch, Galatia and Phrygia, thereupon returning and making Ephesus his headquarters for some three years. ${ }^{25}$ It is during his absence that Luke places the advent of Apollos and the founding of the Baptist community, ${ }^{26}$ but, judging by the strength of the sect and allowing for Luke's scanty sources, it is quite probable that it had been founded some years earlier. Apollos was soon converted to Christianity by Paul's neophytes, Aquila and Priscilla, and the Apostle, on his return, converted twelve other men of the same persuasion. Though Luke rather implies that this was the whole community he is mistaken, for the Fourth Gospel, written at Ephesus half a century later than the period in question, indicates that the Disciples were still strong there.

Paul's First Epistle to the Corinthians, written at Ephesus (xvi. 8, 19), has several allusions to the Disciples of John. The section i. $13^{-17}$ is apparently directed against Apollos who laid much emphasis upon baptism. If it were established, as it is asserted by an early writer, that Simon Magus $^{27}$ was a Disciple of John, we might see in the phrase "power of God" 28 a catchword borrowed from the Disciples by the Apostle. It is probable that the words "we preach

${ }^{2}$ Reuss, Les Actes des Apôtres, 1876, p. 187; W. B. Smith, Der vorchristliche Jesus, $2 \mathrm{~d}$ ed., 1911, Chap. I.

- Acts Xx. 31.

* Acts xviii. 24-xix. 7.

"Clementine Homilies, XXIII.

1 Cor. i. 18; cf. Acts viii. 10. 
a Messiah crucified" (verse 23) indicate that Christs of other types had been preached at Corinth, and one of these was not improbably the Messiah of the Baptist. In ii. $\mathbf{1 0}^{29}$ and also in Ephesians v. $14^{30}$ we have quotations from a lost work, the Revelation of Elias. It is remarkable that the only two known quotations from this book should be found in letters either written from or addressed to Ephesus, surely a strong indication that it was early current, if not indigenous, there. Remembering that John was early given the rôle of Elias, ${ }^{31}$ and that the author of the Fourth Gospel, with his eye on the Disciples at Ephesus, thought it worth while to contradict this ascription, ${ }^{32}$ which, nevertheless, persisted in circles drawing heavily on Ephesian sources, ${ }^{33}$ it is surely legitimate to conjecture that this lost Apocalypse was one of the sacred books of the Johannites. As the quotation in Ephesians v. 14 is also very like a verse in the Odes of Solomon, VIII, 3, 4, this surmise is still further corroborated.

The most certain reference to the Disciples in I Corinthians is found in the saying that "our fathers.... were all baptized unto Moses in the cloud and in the sea." ${ }^{34}$ As nothing is known of this in Jewish literature, Paul was either inventing it or drawing on some very recent legend. If the former, his meaning is plain: As the baptism of John prepared for the triumph of Jesus, so the triumph of Joshua (in Greek, "Jesus") was prepared by a baptism in the Red Sea, by Moses. There are two indications, however, that he was following an earlier, Ephesian, source, and, if so, it was surely not unconnected with the Johannites. A somewhat similar thought is found in the Odes of Solo-

* According to Origen, Ambrosiaster and Euthalius, Encyclopadia Britannica, 11th ed., II, 173 .

"According to Epiphanius, ibid. Of course "the Messiah" here need not refer to Jesus.

"Matt. xi. 14. "John i. 21.

w In the Pistis Sophia which quoted so much from the Odes of Solomon; Bauer, op. cit., 109; also in Justin Martyr's (Ephesian) Dialogue, 49.

1 Cor. x. $1,2$. 
mon, ${ }^{35}$ and, far more explicitly, the same comparison of Moses with the Baptist is made by Justin in his Dialogue with Trypho, ${ }^{36}$ an Ephesian production.

It is highly probable that I Cor. xii. 2 is also an allusion to the yet unconverted Disciples. It is true that any one who did not believe in Jesus might anathematize him, but it is hard to imagine who, save the Johannites, could have done so, claiming to speak by the Spirit. With them emphasis on the Holy Spirit was a cardinal doctrine, dating, according to $Q$, from the first days. Further evidence of their opposition to Jesus will be given later.

Finally, it may be left undetermined whether baptism for the dead ( I Cor. Xv. 29) was one of their customs. Paul does not disapprove of it.

The Epistle to the Ephesians ${ }^{37}$ has, apart from many reminiscences of the Odes of Solomon, at least three allusions to the Disciples of John. The expression "sealed with the Holy Spirit of promise"38 is certainly borrowed from the "baptism with the Holy Ghost" promised by John, as is proved by the statement of Irenaeus (an Ephesian by birth) that "baptism is the seal of eternal life."39 The second reference is the emphasis on "one baptism" ;40 the third is the citation from the Revelation of Elias, mentioned above.

It is sometimes thought that other Pauline epistles were written from Ephesus, ${ }^{41}$ and still others addressed

"Ode XXXIX, 6. Cf. E. A. Abbott, Light on the Gospel from an Ancient Poet, 1912, p. 480 .

Chap. 49.

"Space will not allow me to go into the much debated question of the authorship and destination of this epistle. I can only say that, after careful study of the subject, I regard the early date of the letter, and its connection with Ephesus, as certain. I think it also probable that it is by Paul and written to a circle of Asiatic churches of which Ephesus was the chief.

E Eph. i. 13. Matt. iii. 11.

"Exhibition of the Apostolic Teaching," Chap. 3; Texte und Untersuchungen, XXXI, 1907.

${ }^{\infty}$ Eph. iv. 5.

"Galatians and Colossians; cf. Harnack, Die Entstehung des neuen Testoments, 1914, pp. $106 \mathrm{f}$. 
to persons in that city, ${ }^{42}$ but in none of them is there anything pertinent to the present subject.

The next literature bearing directly on the Ephesian Disciples is found in the Johannine writings. The Apocalypse has nothing on them, but the very evident attitude of the Fourth Gospel to them has already been pointed out, its whole treatment of the Baptist, indeed, being conditioned by polemic tendency. A very striking, though I believe hitherto unrecognized, allusion to them is found in I John v. 6: "This is he that came by water and the blood, even Jesus Christ; not with water [of baptism] only, but with the water and with the blood [of the eucharist and passion]." The Johannites had, of course, no eucharist, but only baptism, and the words apply better to them than to the Docetists. Another reference is I John iv. I-3 about the spirits which confess not that Jesus Christ has come in the flesh, or that he is of God. This also is usually and quite rightly applied to the Docetists, but did not their doctrines arise naturally from the "Christless Christianity" of the Baptists? The Ignatian epistles have much about these heretics, but nothing else clearly indicating the Disciples. Justin Martyr, at Ephesus, mentions the "Baptists" as a Jewish sect. ${ }^{43}$ It is beyond the purpose of the present paper to go into the later literature of Ephesus-the Acts of John, the writings of Ignatius, Papias and the rest.

It remains to be proved that we have, in the "Odes of Solomon," a work written by one of the Disciples. Since their publication, in I909, by their brilliant discoverer, $J$. Rendell Harris. they have been the subject of a vast amount of study. Many hypotheses of their origin have been advanced to account for the peculiar phenomena of their dogma. For they present the strangest mixture of Judaism, (supposed) Christianity and heresy hitherto ever

"Rom. xvi and parts of 2 Tim.

“Dialogue with Trypho, Chap. 80. 
met with, and all of it set forth in a style of poetry and exaltation far above the usual level of anything outside the Gospels or Pauline epistles. Full of phrases which strongly suggest the thought of New Testament writers, there is not one indication that the author knew a single book now in our canon. Recognizing the validity of God's law and of worship in the temple at Jerusalem, he is yet broad in his sympathies and highly spiritual in his interpretation of circumcision and sacrifice as of the heart. His great Messianic passages show striking similarities to the story of the Gospels along with divergencies which are difficult to account for. He speaks of the mother of the Messiah now as the Holy Spirit and now as a Virgin; he alludes to his death by crucifixion, and his descent into Hades, but knows nothing of his resurrection. He speaks of Father, Son and Holy Spirit, but never mentions the name of Jesus nor any of his words nor any events in his ministry save the ones just recorded. Full of allusions to baptism, these songs know nothing of the eucharist. Written as the continuation of a Jewish work of the first century before Christ, they narrowly escaped adoption into the New Testament canon. These and many similar puzzles are the conditions for solving the problem of the date and provenance of the newly found work. I believe that they all suggest Ephesus, a date earlier than I Corinthians, and an author whose point of view agrees in all respects with what is otherwise known of the Disciples of the Baptist.

First, as to their place of origin. At present they are known only in Syriac, ${ }^{44}$ but it is probable that they are a translation from the Greek, for it is certain that they were early read in the Greek, and were inserted in this language in some manuscripts of the New Testament. Harris at

" J. R. Harris, The Odes of Solomon, 2d ed., 1911, pp. 35ff; Burkitt, "A New MS of the Odes of Solomon," Journal of Biblical Literature, XIII, 1912, pp. $372 \mathrm{ff}$. R. H. Connolly in Journal of Theological Studies, 1913, pp. $531 \mathrm{ff}$. 
first suggested a Syrian, or Syro-Palestinian origin, and this ascription has been accepted by most scholars. ${ }^{45} \mathrm{~F}$. C. Burkitt, ${ }^{46}$ however, thinks that they originated in the Monophysite Syrian colony in Egypt, which produced translations of the Acts of Peter, Paul and Luke. The distinguished Syriac scholar is perhaps right about the provenance of the Syriac translation, but, notwithstanding the fact that the Odes were extensively used in the Pistis Sophia, there is slight reason to suppose that they originated in Egypt. Far greater and earlier use of them can be found elsewhere.

The merit of first seeing that the Odes originated at Ephesus belongs to Mrs. Margaret D. Gibson. ${ }^{47}$ While editing the Syriac commentary of Ish'odad of Merv (c. 850) on Paul's epistles she found this note to Ephesians v. 14: "It is said to one of the Believers who was at Ephesus; because at that time there were many at Ephesus with different gifts of the Spirit; and they had this also that they could make psalms and hymns like the Blessed David." Again, in Theodore of Mopsuestia (fourth century) she found, in the same connection: "Some say that at that time many graces of the Spirit were given to them, among others that they could make Psalms, as it was given to the Blessed David to do before the advent of Christ." Moreover she found to this verse (otherwise attributed, as we have seen, to the Revelation of Elias) ${ }^{48}$ a fairly close parallel in Ode VIII, 3, 4: "To speak with watchfulness by his [the Lord's] light: Rise up and be raised, ye who for a time have been laid low; tell forth, ye who were in silence [i. e., dead]; speak! since your mouth hath been opened." Further she finds that Severianus says that in

" Realencyklopädie für prolestantische Theologie und Kirche, XXIV, 375ff.

" Loc. cit in note 44.

"Athenoum, 1914, pp. 530, 559.

- This fact causes no difficulty. As we have seen good reason to believe that the Revelation of Elias was an Ephesian production, probably the work of a disciple of John, both the Ode and Paul may have quoted from it. 
this verse Paul is referring to a spiritual psalm, and she suggests that the words about "psalms and hymns and spiritual songs" in Ephesians v. I9 apply to the Odes. On conferring with Dr. Mingana she found that he agreed with her, and proposed that the Odes be considered of Ephesian origin and earlier than the Gospels.

Dr. Harris, without definitely committing himself, has spoken favorably of this hypothesis. ${ }^{49} \mathrm{He}$ points out a further striking parallel between the language of Paul, Ephesians v. 15-I8, and that of Odes XI and XXXVIII. "Be not unwise," says the Apostle, "but wise... . be not foolish but understand what the will of the Lord is. And be not drunken with wine, wherein is riot, but be filled with the Spirit." With this compare the same thought in Ode XI, 6ff: "Speaking water touched my lips from the fountain of the Lord plenteously: and I drank and was inebriated with the living water that doth not die; and my inebriation was not one without knowledge, for I forsook vanity." Again, in Ode XXXVIII: "They invite many to the banquet and give themselves to drink of the wine of their intoxication, and remove their wisdom and knowledge and make them without intelligence." The same contrast between hurtful and spiritual intoxication is made by Theodore of Mopsuestia.

I shall now proceed to confirm the hypothesis thus started by pointing out the numerous parallels or references to the Odes in other extant Ephesian literature, beginning with some in the middle of the second century, and working backward to the middle of the first.

The Leucian Acts of John have two distinct parallels to the thought of the Odes. The first is that of the "unenvious God,"so all the more striking because it is in a way a con-

- Athereum, 1914, pp. 760f. His suggestion that Eph. v. 14 comes from the missing second Ode is not necessary. Cf. last note.

- Acts of John, 55. Ode III, 7, as translated by Ungnad and Staerk: Die Oden Salamos, 1910: "weil es keinen Neid bei dem Herrn gibt." 
tradiction to the "jealous God" of the Decalogue. The second is the comparison of Christ to a mirror. ${ }^{\text {st }}$

Justin Martyr, who at least spent a good part of his life at Ephesus, speaks of early Christian hymns (First Apology, XIII), and in his Dialogue with Trypho (a debate held at Ephesus) Chap. 22, uses language about the non-observance of the Sabbath closely parallel to that found in Ode XVI, 15.

A resemblance in Irenaeus has been pointed out by Harris to Ode IV, 9. The cup of milk in Ode XIX recalls the language of Irenaeus Against Heresies, IV, 38, . $^{52}$

Ignatius, who lived in constant intercourse with the Ephesians, seems to have borrowed from the Odes (XI, $6,7)$ the phrase about the "living and speaking water" (ad Romanos, VII). A far more striking similarity is found in the thought of his Epistle to the Ephesians XIX, that the "three shouting mysteries" of Mary's virginity, and the birth and death of the Lord, "were wrought in the stillness of God," compared with Ode XIX, where it is said that the mixture of God's milk whereby (apparently) the Virgin conceived, was "given to the worlds"s without their knowing it." The pre-existence of the Messiah is also found in Ode XLI, I4-I6 and in Ignatius to the Magnesians, VI, I.

The parallels between the Odes and the Gospel and Epistles of John ${ }^{34}$ are extremely numerous. Harris recognized at once that he was in the atmosphere of Johannine thought, ${ }^{\text {ss }}$ and yet he was unable to point out a single direct quotation of one from the other. Harnack emphasized

"Ode XIII, 1; Acts of John, ed. M. R. James in Texts and Studies, V, 1, 1897; Bonnet, Acta Apost. Apoc., II, 1, 1898, p. 198.

"Conybeare in Zeitsch. f. "tt. Wissenschaft, 1913, p. 96.

" On reading the plural, cf. Newbold in Journal of Bib. Lit., XXX, 189.

"The Ephesian origin of this is all but universally recognized. W. Bauer, however, (Das Johannesevangelium, in Lietzmann's Handbuch zum N. T., 1912) thinks an Antiochian or Egyptian provenance possible, though not so probable as an Ephesian.

- See also P. Wendland, Die urchristlichen Literaturformen, 1912, p. 245. 
this judgment of Harris; although reference to the name of Jesus, to his earthly life, his word and example fails in the Odes, yet in other respects "even in details the thought of the Fourth Gospel is prepared for it." The Odes are

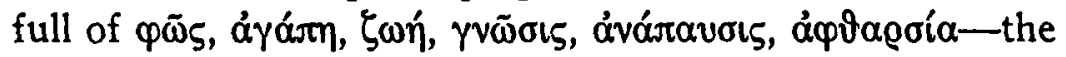
very staples of Johannine theology. It would be entirely superfluous for me to enumerate in this place all the parallels that can be found. For the greater part of them I refer to the notes of Harris in his second edition. But a few which have either escaped him, or which have particular bearing on my thesis, require to be given.

In Ode III, II, "he who has pleasure in the Living One will become living," we have a verse that might well find a place in Jesus's sermon on the raising of Lazarus, John xi. $25 \mathrm{ff}$.

Ode IV is a discussion of the theme in the opening words: "No man, O my God, changeth thy holy place; and it is not [possible] that he should change it and put it in another place: because he hath no power over it." The author is arguing that the Jerusalem temple is the only proper place to offer acceptable worship to God, and Harris believes he sees the occasion of the Ode in the closing of the temple at Leontopolis in Egypt, 73 A. D., a place of worship started as a substitute for that at Jerusalem. This hazardous identification is made impossible by considerations of chronology. If (as Harris now seems disposed to recognize) the Odes are quoted in Ephesians, and if (as will be shown below) they are alluded to nine times in I Corinthians, their date must be prior to $55 \mathrm{~A}$. D., and they cannot refer to an event twenty years later. And yet I believe we have an important historical fact recorded here, one which also left its mark on the Fourth Gospel. $I$ infer that there was a real discussion of the validity of worship outside of the temple, and that the author took the narrower Jewish view. In time, however, a broader 
spirit came to prevail, and, as the question continued to be a burning one, the author of the Fourth Gospel devoted to it the important section (chap. iv) in which Jesus discusses it with the woman of Samaria and enunciates the great principle that "God is a spirit and they that worship him must worship him in spirit and in truth," "neither in this mountain, nor in Jerusalem." Th6 procedure is highly characteristic of the method of "John" whose treatment of his subject is entirely from the standpoint of his own day, and who seems to have selected from his sources chiefly that which he thought needed to be corrected.

Verses on the living water in Odes VI, XI and XXX find cognate thoughts in John iv. 14, vi. 35 , vii. 37 .

The "abundant room in Paradise" (Ode XI, 20) is but another name for the "many mansions" of John xiv. 2. (Also found in Enoch 39, 4 and Secrets of Enoch 61, 2.)

"The dwelling-place of the Word is man: and its truth is love," (Ode XII, Ir) was certainly in the mind of him who wrote: "The Word became flesh and dwelt among us .... full of grace and truth" (John i. I4).

The "door" of Ode XVII, Io is the "way" of John xiv. $5,6$.

Speaking in the person of one greater, our poet calls himself "the shining light, the Son of God." 57 It cannot be without significance that this is precisely the title applied in the Fourth Gospel by the Baptist to Jesus (i. 6ff) and by Jesus to the Baptist (v. 35).

The Apocalypse also has a number of ideas in common with the Odes. One similarity is the use of "Hallelujah" by both. Much space in both writings is given to Paradise and to crowns and rivers and trees of life. The Lord is

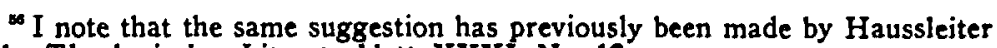
in the Theologisches Literaturblatt, XXXI, No. 12.

"I "Wurde ich das glänzende [Licht] der Sohn Gottes genannt." UngnadStaerk, Ode, XXXVI, 3. 
the sun in Ode XV, 2 and in Revelation xxi. 23. It is not to be doubted that the great dragon with seven headsnamely Rome-in Ode XXII, 5, is the same that appears in Revelation xiii. 3 and xvii. 9 .

Similarities in thought or language to the synoptic gospels are almost entirely wanting. I have noted only three, and it is highly significant that two of these certainly, and probably the third also, are to passages about John the Baptist. They will be evaluated below.

There is one parallel to James-the simile of the mirror -but I have noticed none to Hebrews, 2 Peter or Jude. To I Peter, on the other hand, there are three, and though two of them happen to have resemblances in Ephesians, they can hardly be explained simply as having been borrowed from this epistle by the author of I Peter, for he is closer to the Odes than is Paul. Be it remembered that this writing is a pseudepigraph claiming to originate in Rome but addressed to the churches of Asia and of neighboring provinces. The "sojourners and pilgrims" of ii. I I remind one of the similar expression in Ode III, 7. In saying that "the Spirit of Christ testified beforehand to the sufferings of Christ" I believe the author had the Odes in mind. (See below.) The remarkable association of the descent into Hades with baptism found in iv. $6 \mathrm{ff}$ and in the Odes will also be weighed in its proper place.

Among Paul's letters I have found no parallels to the Odes in Thessalonians, in Galatians, in Philippians, in Philemon or in the Pastoral epistles. There is one parallel in Colossians (also in Ephesians), there are two in 2 Corinthians, four in Romans, nine in I Corinthians and nine in Ephesians. This distribution strongly suggests that Ephesus was the home of the Odes, for I Corinthians was written from that city, 2 Corinthians and Romans probably soon after leaving it. Taking up the epistles in their inverse chronological order: 
Three of the parallels to Ephesians have already been pointed out in quotations from Mrs. Gibson and Dr. Harris. Others are: The use of "the Beloved" as a title of the Christ, Eph. i. 6, Ode III, 5. "I shall be no stranger," Ode III, 7 and Eph. ii. 19. The use made of Psalm Ixviii. 18, "leading captivity captive" in Eph. iv. 8 and Ode X, 3. The descent into Hades in Ode XLII and Eph. iv. Io. The comparison of the love of Christ and his people to that of man and wife (also in the Old Testament) in Ode XLII, 9ff and Eph. v. 32. The pleroma of Col. ii. 9, Eph. iii. 19, and iv. $\mathrm{I} 3$ is probably the "fulness" of Ode XIX, 5. That the reference to baptism as "the seal of the Holy Spirit of promise" is borrowed from the Odes has been proved above (Eph. i. 13).

In Romans xi. 29 the idea that "the gifts and calling of God are without repentance" seems to be dependent on Ode IV, II. "Redeemed by grace" and "Justified by grace" (Odes IX, 5 and XXIX, 5) are found again in Rom. iii. 24. In Ode X, 4 the idea that the service of God is freedom from sin is given in converse form in Rom. vi. 18. In Ode XXIV, 3 the simile of the abysses crying to the Lord like women in travail strongly suggests the metaphor of the creation groaning and travailing together in Rom. viii. 22.

The association of Father, Son and Holy Spirit, rare in very early Christian literature, is found in Ode XIX and in 2 Cor. xiii. 14. "Subduing the imaginations of the peoples" (Ode XXIX, 8) recalls a similar expression in 2 Cor. X. 5.

In I Cor. striving for the crown that cannot wither (ix. 25) is a combination of the ideas brought forward in Ode I and IX, 9. The joining of the believer to God is spoken of in Ode III, 8 and I Cor. vi. 17. The assertion that God is zealous to make known to us his gifts is borrowed from Ode VI, 5 by I Cor. ii. 12. The metaphor of 
the mirror (xiii. I2) was certainly suggested by Ode XIII, I. "I have put on incorruption through his name and have put off corruption by his grace" $(\mathrm{XV}, 8)$ is language as close as possible to that of Paul in I Cor. xv. 53. The comparison of God and his people to the head and members (Ode XVII, I4) suggested I Cor. vi. 5. "Milk for babes" ( $I$ Cor. iii. 2) is a reminiscence of Ode XIX. The parallel between Ode XXXIX, $6 \mathrm{ff}$ and I Cor. $\mathrm{x} .2$ has already been discussed.

I believe there is one other local allusion in the Odes, which has also great intrinsic interest. It is in Ode XXIII :

"His [God's] thought was like a letter; his will descended from on high, and it was sent like an arrow which is shot violently from the bow: and many hands rushed to the letter to seize it and to take it and to read it: and it escaped from their fingers and they were affrighted at it and at the seal that was upon it. Because it was not permitted to them to loose its seal: for the power that was over the seal was greater than they. But those who saw it went after the letter that they might know where it would alight, and who should read it and who should hear it. But a wheel received it and came over it: and there was with it the sign of the kingdom and of the government: and everything which tried to move the wheel it mowed and cut down: and it gathered the multitude of adversaries, and bridged the rivers and crossed over and rooted up many forests and made a broad path. The head went down to the feet, for down to the feet ran the wheel, and that which was a sign upon it. The letter was one of command, because all places were assembled together $;^{58}$ and there were seen at its ${ }^{39}$ [the wheel's] head the head which was revealed, even the Son of Truth from the Most High Father, and he inherited and took possession of everything.

- "Weil versammelt waren allzumal alle Orte," Ungnad-Staerk.

"As "letter" and "wheel" are both feminine "it" might refer to either. 
And the thought of the many was brought to nought, and all the apostates hasted and fled away. And those who persecuted and were enraged became extinct. And the letter was a great tablet, which was wholly written by the finger of God: and the name of the Father was on it, and of the Son and of the Holy Spirit, to rule for ever and ever. Hallelujah."

In explanation of the above Dr. Harris suggests that some book claiming divine authority may have been published, and that this may possibly have been a "descensus ad inferos," but he confesses his inability to penetrate deeper into the enigma here offered. Mr. Newbold ${ }^{60}$ has proposed a very elaborate interpretation of this ode, finding in it the gnostic conception of the descent of Christ through different worlds on the wheel of the zodiac; he even thinks that the author cryptically indicates the astronomical times of Christ's conception, birth and baptism. His theory is too complicated and precarious to obtain ready assent.

My own solution of the problem may at first appear startling, and I lay no great stress on it, as all that I wish to prove is amply supported by other evidence. Personally, however, I am convinced that this poem contains a most interesting local allusion. "What man is there that knoweth not that the city of the Ephesians is temple-keeper of the great Artemis, and of [her image] which fell down from heaven?"6x In this verse the words "her image"

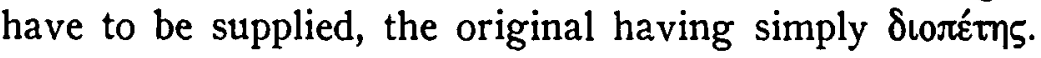
This may have been a meteorite, like the black stone in the Caaba, at some early date roughly hewn into an image. On the girdle and feet of this statue were the far-famed "Ephesian letters," inscriptions in Hebrew characters ${ }^{62}$ con-

- Journal of Biblical Literature, XXXI, 174ff.

"Acts xix. 35.

- Realencyclopädie für protestantische Theologie und Kirche, X, 543; XXI, 619. 
sidered magical, and as charms copied and circulated on papyri. These, I believe, constituted the oracular letters written in cypher (such is the significance of the "seal") shot from heaven to earth like an arrow. It will at once be objected that it would be impossible for a Jewish proselyte to see in these objects of a heathen cult a message from his own God. But there is extant direct proof that the early Christian Fathers regarded these charms as, in a sense, holy. Hesychius and Clement of Alexandria ${ }^{63}$ quote them, and it is remarkable that of the six words they report, two were interpreted respectively as "light" and "truth," common factors of the Odes and of the Johannine writings. Everywhere, indeed, the early Christians, to whom the Baptists may safely be compared, were extremely syncretistic. At Ephesus in particular all was grist that came to their mill. The great doctrine of the Logos was first enunciated five hundred years before Christ, by the Ephesian philosopher Heraclitus. The worship of the unmarried mother Artemis was extensively appropriated by the Virgin Mother of Jesus. ${ }^{6 s}$ It was here that, in the teeth of violent opposition from other churches, she was dubbed "Mother of God." leges of celibates of both sexes devoted to Artemis ${ }^{67}$ were the seed-plots of the later monasteries. The manner of invoking the goddess by a procession was taken over by the local Christians. ${ }^{68}$ A certain natural phenomenon, where the earth gushed up and dust was blown out, was at first called the grave of the snoring Icarus, and then

- Clemens Alex., Stromata, I, 360; V, 415.

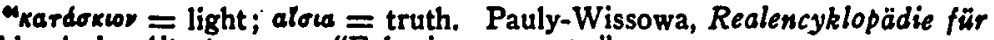
das klassische Altertum, s. v. "Ephesia grammata."

W. Ramsay, Expositor, 1905. See also a letter in the Nation (New York), 1906, LXXXIII, 400.

- Realencyklopädie für protestantische Theologie, XII, 332. $1,269$.

- J. G. Frazer, The Magic Art, 2d ed., I, 37f; Adonis Attis Osiris, 3d ed.,

" On the ropart of Aphrodite cf. Archiv für Religionswissenschaft, 1914, pp. 678f; on the Christian ropral cf. Justin Martyr, First Apology, Chap. 13. 
was renamed the grave of the sleeping and breathing Apostle John. ${ }^{69}$ The feast of Artemis, May 7, was also appropriated to the local tutelary saint. ${ }^{70}$ Nay, more, the worship of Christ was prepared for in a high degree. Just four years before Paul's advent the Ephesian senate and people had passed a decree declaring the Emperor "high-priest, god made manifest and common Saviour of human life."71 All these titles were taken over by the new God-Man, who also appropriated part of the legend and rites of Dionysus, from time immemorial next to Artemis the great deity of Ephesus. ${ }^{23}$ In that city, an early authority"3 informs us, the heathen "numbered wine among his mysteries, and taught that, having been torn to pieces, he ascended into heaven."

It will, therefore, be nothing strange if our author sees in a heathen inscription an oracle written by the finger of God. This idea was the natural deduction from the assumption that the image fell from heaven or from Zeus, the supreme deity identified with Jehovah also by the early Christians (Acts xvii. 28). The fact that the characters were Hebrew would be sufficient in the eyes of a Jew to give them a divine authority, but what they said was doubtless pure hocus-pocus, capable of any interpretation whatever. From the extant magic papyri we know that the names of God and even of "Jesus, the god of the Jews"'4 were to be found on the charms in circulation, and there is therefore nothing remarkable in the statement of our author that he read in the letter the names of "the Father, the Son and the Holy Spirit."

All this, however, was sealed from the heathen, who were unable to decipher the cryptogram. The main bur-

'C. Erbes in Zeitschrift für Kirchengeschichte, XXXIII, 1912, $160 \mathrm{f}$.

"Ibid., 161 and 239.

" Plutarch's Antony.

${ }^{n}$ Dittenberger, Sylloge, II, 802-4.

" Justin Martyr, First Apology, LTV.

"In the Parisian magic papyrus published by Wessely, quoted by W. B. Smith, Der vorchristliche Jesus, 38. 
den of the oracle was something else, namely the downfall of the great goddess and the rise of the true God. This explains why the style of the poet, elsewhere so lucid, is here so cryptic. He was unable openly to attack the prevailing religion, just as John of the Apocalypse feared to speak of Rome and Nero save in cypher. The letter lighted on a wheel-in my interpretation the wheel of fortune, the rota fortunae ${ }^{75}$ which we see in those faithful reflectors of popular beliefs, Cicero's writings. As the wheel of fortune turned, the former head (namely Artemis) ran down to the feet, and a new head came to the top and was revealed, namely "the Son of Truth from the Most High Father, and he inherited and took possession of everything." No words could be more applicable to the fall of one religion and the rise of another. So complete was the triumph that the apostates fled away and the persecutors became extinct.

The wheel had on it "the sign of the kingdom and of the government," namely, of the Roman Empire, regarded at this time by small sects like the Christians as their great protector from the fanaticism of established religions. ${ }^{76}$ It had cut down all its adversaries and crossed all rivers, and gathered into one all peoples. It was naturally associated with fortune, for "Fortuna populi Romani" was emblazoned on its banners. Its fall was also expected with the turn of the wheel, i. e., with the decline of heathendom and the rise of the new celestial kingdom.

Having now said all that seems to bear on the provenance of the Odes, we should find it an easy matter to ascertain their date. If they be indeed mentioned by name in Paul's Epistle to the Ephesians, and frequently alluded to in First Corinthians they must necessarily be earlier than the date of that letter, about $55 \mathrm{~A}$. D. There is

"W. W. Fowler, Roman Ideas of the Deity, 1914, 72ff.

"Cf. 2 Thess. ii. 7; the same bias for Rome is seen plainly in Mark, Luke and Acts. 
one other reference to them, which also points to their antiquity. We cannot, indeed, quote Josephus ${ }^{77}$ in their favor, but there is one pertinent passage preserved by Eusebius. $^{78}$ This historian speaks of a certain Antemon ${ }^{79}$ who maintained that Jesus was a mere man; he then quotes from an anonymous work written against this heretic, apparently about 230 A. D., in which these words occur: "How many psalms and hymns written by the brethren from the beginning celebrate the Christ the Word of God, speaking of him as divine." This is so perfect a description of the Messianic teaching of the Odes that it must needs refer to them, and in so doing testifies to their antiquity. The terminus a quo must have been but a few years earlier, not later than the establishment of the community of Disciples of John (or, if they are still considered Christian, of Jesus) at Ephesus. This may have been somewhat earlier than the time given by Luke, but it is not possible that it should have been within some years of the death of the Baptist.

It is now to be proved that the Odes were composed by a disciple of John. This has already been strongly suggested; for, if they were written at Ephesus before Paul had completed his stay there, what other author is so likely? One can read between the lines of Luke's account that the Baptists were the older and, until Paul's arrival, the stronger sect, and it is certain that their influence was felt for many years.

Let it not be objected that if they had been written by a non-Christian author they would not have become generally accepted, and indeed nearly canonized, ${ }^{80}$ by the

"Antiquities, VIII, 2, 5, speaks of "1005 Odes of Solomon"; he also knew John the Baptist, but probably not our Odes.

"Hist. Eccl., V, 28, 5.

"On him, cf. Harnack, Dogmengeschichte, 4th ed., I, $716 f$.

- They are found in MSS of the New Testament and in old canons; cf. Harris, pp. 3ff. 
Church. Not only were the Jewish scriptures recognized by the Christians, but there are abundant evidences of late Jewish works being treated as inspired. Thus Paul quotes the Revelation of Elias, and Jude cites the Book of Enoch. The Muratorian Fragment, as is well known, places among the New Testament books "Wisdom written by the friends of Solomon." If the conjectures of Luther and Spitta be correct the Epistle of James is but a Jewish work, twice interpolated with the name of Jesus. Our Apocalypse, too, is possibly based on an earlier purely Jewish work, $Q$ also quotes an unknown "Wisdom of God" (Luke xi. 49).

It is impossible here to examine all the theories put forward as to the origin of these poems. One class of scholars finds in them the product of some Christian heresy, whether Gnostic, ${ }^{81}$ or Valentinian, ${ }^{82}$ or Docetic, ${ }^{83}$ or Montanist, ${ }^{84}$ or that of the mystic Bardaisan. ${ }^{85}$ It is sufficient to point out that these theories are mutually destructive and that all have been contradicted. A certain number of scholars, indeed, see gnostic elements in the poems ${ }^{86}$ but even the numerous gnostic parallels pointed out by W. Stölten, ${ }^{87}$. if examined closely, rather confirm than invalidate my theory. Some of his parallels adduced from Poimander, from Mithraism and from the magic papyri, are perhaps pre-Christian. Many other parallels, notably those in the Pistis Sophia, are demonstrably borrowed from the Odes, not by them. Others, from the Apocryphal Acts, from the writings of the Mandaeans and from the Gospel of Nicodemus, point in one way or another to Ephesus and the Disciples of John. But yet gnosticism is not the dominant note of the Odes. They are, says Harnack, and Harris agrees with him, only gnostic in the sense that the Fourth Gospel is so.

\footnotetext{
a Gunkel and Gressmann. * Preuschen.

"Conybeare and Fries. $\quad$ Newbold.

"Dictionary of Religion and Ethics, s. v. "Gnosticism."

"Zeitschrift für neutestamentliche Wissenschaft, 1912, 294.

- Battiffol.
} 
A second type of theory, represented by Spitta and Menzies, regards the Odes as purely Jewish. In a sense this is correct and important, but there are many peculiarities of the poet, e. g., his references to baptism and his Messianic dogmas, that imperatively demand further explanation.

A third hypothesis, represented by Harnack, is that the Odes were originally Jewish and have been interpolated by a Christian. Professor Harnack feels called upon to apologize for this intrinsically improbable hypothesis of interpolation, and I think that recent careful research ${ }^{88}$ has settled definitely that the Odes are of a single piece. And yet the hypothesis of Harnack and his followers is the logical result of their clear vision that parts of the Odes could have been written by no Jew, and other parts by no type of Christian hitherto known. Harnack confesses, "I know no Christianity like this."

A fourth theory, represented by Harris, Bernard and Abbott, is that the Odes were written by a Christian at a date so early that dogma had not yet become stereotyped. Belief is still inchoate; thought is struggling to the perfect expression not yet attained. This theory, too, accounts for many of the known facts, and yet I think it can be shown that some things in the Odes-failure to speak of Jesus by name, of his word or example, or of the eucharist -are not compatible with it. Practically the only theory left is that here presented, that the Odes are the product of a Messianic movement similar to Christianity in many respects, but not identical with it; and when, in addition, many points of contact with what is otherwise known of the Disciples of John, can be found, a satisfactory answer to the hitherto unsolved. problem will at last, it is hoped, have been reached.

* G. Kittel, Die Oden Salomos überarbeitet oder einheitlichP 1914. R. H. Connolly, Journal of Theological Studies, 1912, 298ff. 
The author accepts the whole Jewish ceremonial law, just as did pre-Pauline Christians. The temple at Jerusalem is God's only true sanctuary (Ode IV). Circumcision is so highly prized that even the elect archangels are sealed with it. ${ }^{89}$ That he insists on circumcision of the heart, is no proof that he rejected that of the body, any more than the same metaphor, Jeremiah iv. 4, is proof that he rejected the physical sign. At the same time the author is a missionary to the Gentiles (Ode $\mathrm{X}$ ), and is perhaps one himself by birth ${ }^{\circ 0}$ (Ode XLI). We know that even the Jews at this time received proselytes into full fellowship with themselves, on condition of circumcision, and we also note, in our earliest and best source for John the Baptist, that there is especial reason to think that he welcomed Gentiles to his community. ${ }^{92}$ Indeed his special note, "conversion," is struck in at least one of the Odes $(\mathrm{X}, 3)$. The author is also an observer of the Sabbath: emphasizes the fact that God rested on it, and apologizes for the continued labor of sun and stars on that day "because they know no better." 92 The author is, moreover, deeply versed in the Jewish scriptures.

The high moral tone of the poet is undeniable. He urges men to "pray without ceasing." 93 This is one of the very rare instances in which his language recalls that of a Synoptic gospel (Luke xviii. Iff). It is noteworthy that the same gospel informs us that John taught his disciples

- This is certainly the meaning in Ode IV, 8, proved by comparing it with Inbilees, XV, 27.

"This interpretation of the words "I am of another race" is far from certain. Just as the Christians were early called "the third race," so the author may have conceived of his own sect as a "chosen people," apart even from the Jews. Bacon, Expositor, 1911, I, 330, sees in these words not a reference to the poet's race, but to adoption by the Messiah.

Matt. iii. 9 = Luke iii. 8.

- This is my interpretation of Ode XVI. Harris draws from it the opposite conclusion, being unduly influenced by a similarity of language in Justin Martyr, Dialogue XXII. But the two opposite points of view are but illustrations of Romans xiv. 5, where it is said that even of the early Christians, some do, and some do not, esteem one day better than another.

"Ode VIII, 23: "ask without ceasing" (Fleming); "ask again and again" (Ungnad-Staerk). 
to pray (xi. I). In noting the same fact Tertullian (Against Marcion, IV, 26) is probably not drawing so much on Luke as on his own experience with the Disciples. The asceticism of the author is also plain. Wine is never mentioned save with abhorrence. The spiritual food of believers is "milk and honey"94_exactly the fare that we have already seen given by second-century writers to the Baptist and his followers. This food is treated allegorically and mystically, not sacramentally; but it is surely significant that no sacramental use is made of flesh, of bread or of wine. The latter, indeed, is so much detested that its use is said to have been introduced by "a bridegroom who corrupts" and "a bride who is corrupted." Asking who these may be, the poet is told: "This is the deceiver and the error: and they are alike in the beloved and in his bride: and they lead astray and corrupt the whole world: and they invite many to the banquet, and give them to drink of the wine of their intoxication" (Ode XXXVIII, 9-13). Harris is unable to identify these corrupters, but suggests Simon Magus and Helena (p. 66). It is worth while remembering that they were said to be Disciples of John, and that other members of the community were dissatisfied with them. (Clementine Homilies, XXIII).

One also thinks of Cerinthus, an Ephesian, said to have held sensual views of paradise as a place given over to banquets and marriage ceremonies (Eusebius, H. E. VII, 25). His date, however, would be decidedly too late, and a far better identification is suggested by turning to Mark ii. 18-20: "And John's disciples and the Pharisees were fasting: and they come and say unto him, Why do John's disciples and the disciples of the Pharisees fast, but thy disciples fast not? And Jesus said unto them, Can the sons of the bride-chamber fast, while the bridegroom is

${ }^{N}$ Harris, p. 80. 
with them?' Here we have the point at issue between the two young sects stated from the opposite side, and with a similarity of phrase that cannot be accidental. Not that the pericope in Mark is an authentic reminiscence of the "historic Jesus." It has on independent grounds been recognized that this is but one of the numerous places in the gospel, in which some controversy or situation of the early church has been referred back to Jesus.95

The metaphor of Christ as the "bridegroom" is put into the mouth of the Baptist by the Fourth Gospel (iii. 29), whereas the title "beloved," in the Ode applied to the deceiving bridegroom, is appropriated to Christ in Ephesians i. 6. Still more to the point is that section of our oldest source dealing with John the Baptist, which tells us that Jesus was called a "glutton and a wine-bibber" by those who did not like his "eating and drinking" (Matt. ix. 19). Finally we have already noted that the Sabaeans regarded Jesus as the corrupter of their sect. ${ }^{96}$ The "bride" in the Ode is hardly a more definite figure than in the gospels; doubtless the Christian church is vaguely thought of.97

One of the most decisive facts in favor of my thesis is that, while the Odes have not the remotest reference to the eucharist, ${ }^{98}$ they are full of allusions to baptism. ${ }^{99}$ Similarities in phrase between them and the baptismal services and Epiphany hymns of the Eastern Church put beyond doubt the fact that the numerous appearances of living p. 486 .

Wellhausen, Markuskommentar, ad. loc. Bousset, Kyrios Christos, 1913,

- Neander, Church History (English, 1866), I, 447.

" "Some gnostic society," says Bruston, in Zeitschrift für neutestamentliche Wissenschaft, 1912, 111 .

- Burkitt sees in Ode XXI, 4, "Increasingly helpful to me was the thought of the Lord, and his fellowship in incorruption," some allusion to the eucharist. What can it be? Journal of Theological Studies, 1912, 383. F. C. Conybeare thinks that the two cups of milk in Ode XIX, compared with Irenaeus, Adv. Haer., IV, $-38,1$, are the two elements of the eucharist. Quite impossible. Zeitschrift $f$. nt. Wissenschaft, 1913, 96. All others are agreed that the Odes have nothing about the eucharist.

G. Diettrich, in Die Reformation, May-August, 1910; J. H. Bernard, in Jourmal of Theological Studies, October, 1910 and in his edition of the Odes, 1912 ; R. A. Aytoun, Expositor, 1911, II, 338ft. 
and speaking water, of crowns and white robes, of seals and of signs-even though this imagery be in part borrowed from older Jewish sources-allude to the one sacrament of the Johannites. Professor Harris, who once doubted, has now become convinced of this. ${ }^{100}$ His earlier objection ${ }^{101}$ to the theory of Bernard, who demonstrated the allusions to baptism, namely that "the weak point in his argument lies just here, that the Jewish background of the Odes is too patent to be neglected,"-this answer is the best possible confirmation of our main thesis.

There are also a number of small fingerposts pointing to John the Baptist. The poet, speaking in the person of one greater, says: "I was clothed with the covering of thy Spirit and thou didst remove from me my raiment of skin" (Ode XXV, 8). Dr. Harris's note on this is very learned and very abstruse; I venture to think that a simpler explanation will be found by turning to the early records of the Baptist. John, like his parents (Luke, i. 4I, 67) was filled with the Holy Ghost, and he was also clothed in "a leathern girdle and camel's hair," or, as some manuscripts read, "camel's skin"102 (Mark i. 6). The dove which fluttered over the head of the Messiah (Ode XXIV, I) is the same dove which came to Jesus after his baptism by John (Mark i. 10). In Ode XXVIII, 3 we read: "My heart is delighted and exults like the babe who leaps in the womb of his mother." The same phraseology is used of John in Luke i. 4I. Again the words: "I was called the shining light, the Son of God," 108 vividly recall the title applied by John to Jesus and by Jesus to John in the Fourth Gospel (i. 6; v. 35). Harris observes that the description of the dove flying above the Messiah, supported as it is by citations from second century writers, points to the use of some lost

${ }^{100}$ Expositor, 1912, III, 114ff.

201 J. R. Harris, The Odes of Solomon, $2 d$ ed., 1911, p. 28.

E. Nestle in Zeitsch. f. nt. Wissensch., 1907, p. 238.

is Ode XXVI, 3, Ungnad-Staerk. 
apocryphal gospel. I agree with him that it, as well as the other passages just enumerated, point to the use of some lost source, only it is not a gospel but some writing about John the Baptist, known and used, either directly or indirectly, by the evangelists. Possibly it was the Revelation of Elias.

I have left until last one class of passages-the Messianic-because of their supreme importance, both for the present question and for the development of Christian dogma. That there is in the Odes a very strong and definite Messianic hope is exactly what we should expect from a Disciple of John. On the other hand we should not expect them to refer to specific facts in the life of Jesus, as, in one or two instances, they have the superficial appearance of doing. This appearance can be accounted for in three ways: (I) The Odes may have been written by a Disciple soon after his conversion to Christianity, when as yet he had heard little of Jesus, and did not accept the sacrament-perhaps Pauline in origin-of the eucharist. (2) Without accepting Jesus as the Messiah it is possible that the ideas of the sect in general, or of this author in particular, may have been colored by contact with Christian Messianic ideas. (3) It is possible that the resemblances between the Odes and passages in the New Testament are due simply to the fact that both drew on common sources for their Messianic dogmas. If there are really allusions to facts in Jesus's life, one of the two former alternatives must be selected; nevertheless I believe that the third one is correct, and that the similarities are due to common sources of inspiration, or possibly to borrowing by the Christians from the Baptists.

In estimating the whole evidence the omissions are as significant as are the parallels. Why does not the name of Jesus occur? It is no retort to ask why the name of John is also passed over in silence, for there is no special occa- 
sion to allude to him, but there are numerous passages of a Messianic import, which, did they really refer to Jesus, could hardly have avoided his name. Methodist hymns rarely, if ever, mention John Wesley, but they are full of the name of Jesus. Neither is the answer of Zahn satisfactory, namely that the author is trying to put himself in Solomon's place. All the pseudepigrapha are completely lacking in historical imagination. The name of Jesus was interpolated in prophecies attributed to ancient worthiese. g. in 2 Esdras vii. 28 -even where it was originally wanting.

Secondly, why do all references to Christ's earthly ministry, word and example, fail? Paul's rather surprising indifference to all but the death of the Lord cannot be adduced as a parallel to this, for, however Paul's ideas came to him; whether from other men, or, as he frequently asserts, by direct revelation, he at least states them as historical facts, and applies them to a man Jesus. I see no explanation for the glaring omissions of our poet save that the whole body of evangelic tradition was unknown to him.

Thirdly, why are his statements about the Messiah which agree with Christian doctrines, mixed with others contradicting the New Testament writers? Why, for example, is the Holy Spirit sometimes called the mother of the Messiah (as also in an apocryphal gospel), and why, instead of ascending into heaven, does the Saviour descend into hell? Why are the crucifixion and the sign of the cross alluded to in such extremely vague and dubious terms, suggesting a background not of history but of $a$ priori speculation? I am sure there is not one Messianic passage in the Odes not to be more satisfactorily accounted for by turning to earlier Jewish writings, than by recourse to the New Testament.

I need not pause long over such dogmas as that of the 
pre-existence of the Messiah, and the use made of the term Logos. The latter conception was a natural offshoot from the speculations of Plato and the Stoa, and both ideas had been adopted and developed by Jewish writings, particularly by the Wisdom of Solomon (c. 30 B. C.) and by Philo. At the beginning of the Christian era Wisdom had become a second God, existing from eternity, assisting the Almighty in all his works. ${ }^{104}$ It was the creation of this new God, the Logos, which, as Reitzenstein rightly remarks, necessitated the creation of a new religion. ${ }^{105}$ The most striking verse in the twelfth Ode, on the subject of the Word, and one surely in the mind of the author of the Fourth Gospel, is (II): "The dwelling-place of the Word is man." This, too, is true to the Stoa, which taught that the Divine Logos dwelt also in human nature. ${ }^{106}$ It is more than significant that in the Hermetic writings the favorite words of our poet, $\zeta \omega \eta$ and $\varphi \omega_{5}$, are found as predicates of the Logos, who is also called the Son of God. ${ }^{107}$ The preexistence of the Messiah, and his identification with a Divine Being ${ }^{108}$ second only to the Almighty, are dogmas found more than a hundred years before the composition of these Odes, in the Book of Enoch. There (chap. 57) we read: "For from the beginning the Son of Man was hidden and the Most High preserved him in the presence of his might, and revealed him to the elect." It is the very language of the poet: "The Son of the Most High appeared in the perfection of his Father.... and he was known before the foundation of the world."

The Holy Spirit, too, was a common pre-Christian con-

W. Schencke, Die Chokma (Sophia) in der jüdischen Hypostasenspekulation, 1913. He says that in Proverbs viii. 30, instead of "delight" one should read "assistant."

10 Poimandres, 1904, p. 116.

${ }^{100}$ P. Wendland, Hellenistisch-römische Kultur, 1907, p. 16.

${ }^{10}$ P. Wendland, Die urchristlichen Literaturformen, 1912, p. 245.

im R. H. Charles, The Book of Enoch, 2d ed., 1912, p. xxxviii.

'sw Ode XLI, 14, 16. Cf. Ignatius to the Magnesians, VI, 1. 
ception. Not only, according to $Q$, was it an especially prominent feature of the Baptist's preaching, but it is also found in the Psalms of Solomon (c. 48 B. C), and was there brought into connection with the Messiah. ${ }^{110}$ As the Odes were originally published as a continuation of these Psalms it is hard to see how the author could have avoided mentioning the Holy Spirit. In only one way does he develop the function of this being, in making her the mother ${ }^{113}$ of the Son of Man-that ancient synonym for the Messiah. This idea was a natural corollary to the feminine gender of Spirit in the Semitic languages. If the Almighty was the Father of the Messiah, the Spirit inevitably became his Mother.

Now that we have accounted for the Father, the Son and the Holy Spirit, it is not surprising that we should occasionally find them in a close proximity suggesting the later dogma of the Trinity. Thus in Ode XIX, I, 2: "A cup of milk was offered to me.... The Son is the cup, and he who was milked is the Father, and she that milked him is the Holy Spirit." ${ }^{\prime 2}$ As Paul was familiar with the Odes, it is probable that the first Biblical"13 reference to the Father, Son and Holy Spirit was suggested by this passage. But, indeed, divine families of three were common in oriental religion. "Three in one" was an epithet for Hermes, ${ }^{174}$ and there is no doubt that these Odes stand in a close relation to the "Hermetic literature."

Now as to the person of the Messiah himself. No need to pause over the ideas of salvation and a Saviour (Odes V, VII, VIII et saepe). The phrase "God my Saviour" is common in Jewish thought, and one eminent scholar has

${ }^{100}$ Psalm Solomon, xvii. 42. The Holy Spirit is also found in the Mithraic liturgy. Reitzenstein, Die hellenistischen Mysterienreligionen, 1910, p. 45.

"II Ode XXXVI, 3. So in the Gospel of the Hebrews, Jerome in Jes, xi. 2.

2w The reading of Burkitt's new MS of the Odes.

w 2 Cor. xiii. 14.

"Reitzenstein, Mysteriewreligionen, p. 14. 
already noted that the Saviour of these Odes is not Jesus, but God, or his Servant, or at most the Messiah. ${ }^{115}$ The idea of a Saviour God was also common in the heathen world. ${ }^{16}$ Most significant of all, the Messianic ideas of Ode XXIV have been found applied to the Mandaean Saviour. ${ }^{\text {"7 }}$ These Mandaeans, be it remembered, were probably descendants of the Johannites.

In Ode XIX it is stated in the past tense of prophecy that the Messiah is born of a virgin. In asking whether this idea is dependent on the stories in the First and Third Gospels we must remember that it was written a whole generation before them. It is certain that "the gospel of the infancy" is a graft on the older tradition presented by Mark and $Q$, and, had we no other evidence in the matter save the Gospels and the Odes, it would be natural to assume that the later in time borrowed from the earlier. The conception, indeed, arose as a perfectly necessary evolution. Once postulated that the Son of God was to appear as a man, how else could he be born? Thus it was with the other saviour gods and heroes of antiquity. Attis, for example, was the son of Nana, a virgin." "The wise Egyptians," says Plutarch," "think it not impossible that a woman can be filled with the spirit of God and thus conceive." This is exactly the idea of Ode XIX; the extraordinary process by which generation is accomplished is doubtless intended to eliminate all thought of carnal intercourse. ${ }^{20}$

It is interesting and pertinent to note that Ephesus was early the seat of a division of opinion on the virgin

us B. W. Bacon, in the Expositor, 1911, I, 336.

"Cf. Ephesian inscription quoted above.

${ }^{11}$ Stölten in Zeitschrift f. nt. Wissenschaft, 1912, $29 \mathrm{ff}$.

is J. G. Frazer, Adonis Attis Osiris, 1906, $163 \mathrm{ff}$.

"Numa, IV, 62.

${ }^{200}$ I note the emendation to verse 6 proposed by Newbold, Journal of Bib. Lit., XXX, 189, and also those-inspired by an apologetic purpose-suggested by Father Connolly, Jourral of Theological Studies, 1912, $298 \mathrm{ft}$. 
birth. One source for the doctrine was doubtless found in the worship of Artemis. Another source for the gospel story (Matt. i. 23) and also probably for the Odes, is found in Isaiah vii. 14, translated in the LXX "Behold a virgin shall conceive." But, early in the Christian era, Theodotion of Ephesus published another version of the Scriptures, translating the verse correctly, "a young woman shall conceive." It is possibly for this reason ${ }^{122}$ that the Fourth Gospel clearly implies that Jesus was born in a natural way. Though this opinion was maintained by the Ebionites, the other prevailed, and the LXX continued to be cited by Ephesian apologists. ${ }^{123}$

There are two apparent allusions to the cross, the first in Ode XXVII: "I stretched out my hands and sanctified my Lord; for the extension of my hands is his sign: and my expansion is the upright tree;" and Ode XLII, I, 2: "I stretched out my hands and approached my Lord: for the stretching out of my hands is his sign: and my expansion is the outspread tree which was set up on the way of the Righteous One." It is true that it has been proposed ${ }^{124}$ to explain this not as an allusion to the cross but to an ordinary tree as in Psalms i. 3, lii. ro, xcii. 13 etc. But this is hardly tenable. Though the imagery is very probably suggested by the Old Testament account of the stretching out of Moses's hands, ${ }^{125}$ it is almost certain that the author had in mind a cross. It might be argued that this does not necessarily imply a crucifixion, for the cross was an almost primeval symbol. The crux ansata of Egypt was the sign of life and of the resurrection of Osiris. ${ }^{126}$ Again,

Eusebius, Hist. Eccl., V, 8, 4.

120 John was familiar with various versions of the O. T. See W. Dittmar, Vetus Testamentum in Novo, Part I, 1899.

12. Justin Martyr, First Apology, Chap. 33.

im F. Spitta in Zeitsch. f. nt. Wissenschaft, 1913, 259ff.

According to Justin this was a prophecy of the cross (Dialogue with Trypho, Chap. 90).

19m Frazer, Adonis Attis Osiris, 1906, p. 261. 
the saying of Plato that God placed the cosmic soul "crosswise [literally, like the letter X] in the universe,"127 was early seized upon by Ephesian apologists as an anticipation of the cross of Calvary. ${ }^{128}$ But as I am satisfied that the dogma of a crucified Messiah was current before our era, I think it probable that the Odes really express it. The Suffering and persecuted Righteous Man first appears clearly as an ideal in the Persian period of Jewish history, in Isaiah liii. 4ff. Psalm xxii is, according to Briggs, "a more vivid description of the sufferings of Christ on the cross than the authors of the Gospels gave." ${ }^{29}$ That verse I7, "they pierced my hands and my feet," quoted as a prophecy of Jesus's crucifixion by Irenaeus, Justin Martyr, Augustine, Calvin, Bossuet and a host of others, does really refer to this form of execution, has been demonstrated by Kittel. ${ }^{130}$ Commonly practised by the Persians from whom it was borrowed by the Punic peoples and by the Romans, it is elsewhere referred to in the Old Testament (Ezra vi. II).

The idea of the suffering, and possibly the crucified, Messiah is further developed in Second Zechariah, ${ }^{131}$ in a passage early applied to Christ. The Testaments of the Twelve Patriarchs (about I0O B. C.) is of immense importance in the development of Messianic ideas, and contains passages teaching that "a man who reneweth the law in the power of the Most High ye shall call a deceiver; and at last ye shall rush upon him and slay him;"182 and again that "the Blameless One shall be delivered up for lawless men, and the Sinless One shall die for ungodly men."188

in Timaeus, 36B.

20 Justin Martyr, First Apology, LX.

is Commentary on the Psalms, I, 192.

${ }^{20}$ R. Kittel, Die Psalmen, 1914, 84f, 92.

Zech. xii. 10 to xiii. 7.

wo Test. Levi, XVI, 3. Although Charles admits that these words may be original he brackets them. As they are found in all versions, including the Armenian, and in both Greek recensions, they must be genuine.

20 Test. Ben. III, 8. Found in all the versions. 
Fourth Maccabees, vi. 28 clearly states the Christian doctrine of the Atonement, and in Wisdom, composed not long before $30 \mathrm{~B}$. C. and of immense influence on the development of the Pauline Christology, we have the most remarkable verses ${ }^{134}$ of all:

"The wicked said, For if the Just Man be the Son of God, he will help him and deliver him from the hand of his enemies. Let us examine him with despitefulness and torture that we may know his weakness and prove his patience. Let us condemn him to a shameful death."

Of the Assumption of Moses (7-30 A. D.) R. H. Charles says in his edition (I897): "The author's hero is not one who takes up arms in behalf of Israel, but one who, amid the most bitter persecution that ever befell Israel, was faithful unto death, and, lifting no hand in self-defense, committed his cause unto God."

Three post-Christian works may also be cited as evidence. The Zadokite work complains of those who "justified the Wicked One and condemned the Righteous One" (23I). This is certainly not a specific allusion to Jesus's death, even if the author knew of it, but is on an exact par with the verse in James (v. 6): "Ye have condemned, ye have killed the Righteous One; he did not resist you,"a verse which all scholars from Luther ${ }^{135}$ to Bacon $^{136}$ refer not to the Passion but to the sufferings of an ideal Just Man. Fourth Ezra, a Jewish apocalypse, also speaks of the death of the Messiah. ${ }^{37}$ I think that these citations should make it plain that "through the ages one increasing purpose ran." I trust I have not laid myself open to the accusation, brought by Dr. Conybeare against Mr. J. M.

${ }^{2 m}$ II, $18 \mathrm{ff}$.

wu "De passione et resurrectione Christi sagt er [Jacobus] nicht ein Wort," Luthers Tischreden in der Mathesischen Sammlung, ed. E. Kroker, 1903, No. 528.

in Encyclopadia Britannica, 11th ed. s. v. "James."

m 4 Ezra vii. 29. In verse 28 the word "Jesus," and that word only, is an interpolation, lacking in the oriental versions. 
Robertson, of "raking together a thousand irrelevant thrums of mythology, picked up at random from every age, race and clime." ${ }^{\prime 38}$

The idea of the Suffering Just Man was so natural that it may also be found in Plato and the later Stoics. As to the more precise conception, that he should be put to death by crucifixion, that also is found in Plato (Republic, $362 \mathrm{~A}$ ) as well as in Psalm xxii and possibly in Zechariah. This form of execution being the common one was quite naturally thought of, just as burning at the stake became the typical punishment for heresy in Christendom. That our poet really had Psalm xxii in mind in Ode XXVII on the cross, may be inferred from the fact that he quotes from it twice again in the very next poem. ${ }^{139}$ In Justin Martyr's copy of the Bible (at Ephesus) there was also a prophecy, "The Lord hath reigned from the tree," which he accuses the Jews of erasing. ${ }^{140}$ "Bearing the cross," however, had become proverbial, and may be read in Cicero, Artemidorus, Bereshith Robba and Plutarch ${ }^{\text {14x }}$ before it found its way into the oldest Christian document, ${ }^{142} \mathrm{Q}$. As $Q$ knows nothing of the passion of Jesus, ${ }^{143}$ it here furnishes striking testimony to the currency of the idea in proto-Christian circles independently of, and prior to. the crucifixion under Pilate. This evidence is amply supported by other early documents. The saying that Christ suffered "according to the scriptures" ${ }^{144}$ clearly indicates that Paul, Mark, Matthew and Luke all found the essential features of his death set forth in the Hebrew Bible. The author

139 F. C. Conybeare, The Historical Christ, 1914, p. 95.

100 Ode XXVIII, 8 = Ps. xxii. 7; Ode XXVIII, $11=$ Ps. xxii. 16.

${ }^{10}$ To Psalm xcvi. First Apology, XLI; Dialogue, Chap. 73.

${ }^{14} \mathrm{~W}$. C. Allen, Commentary on Matthew, ad locum, X, 16.

${ }^{10}$ Matt. x. $16=$ Luke xiv. 27.

${ }^{14}$ This positive statement of Harnack is supported by the latest student of the synoptic problem, W. Haupt: Worte Jesu und Gemeindeïberlieferung, 1913. He analyzes $Q$ into several strata, but none of them touch the passion.

14 1 Cor. xv. 3; Mark ix. 12; Matt. xxvi. 24; Acts iii. 18. 
of I Peter only puts it a little more explicitly when he says: "The Spirit of Christ testified beforehand the sufferings of Christ." I4s In saying this it is probable that he had the Odes of Solomon in mind. At any rate $I$ think these poems can be adduced in favor of my present contention. Written, in my judgment, wholly without reference to the "historic Jesus," they yet contain vague allusions to a crucified Messiah. They are, in short, a brilliant example of das werdende Dogma vom Leben Christi.

The doctrine of the descensus ad inferos found in Ode XLII offers no difficulty. In the first place our earliest witnesses point to an Ephesian origin for this doctrine as applied to Christ. It is found in the Gospel of Peter, ${ }^{146}$ in Justin Martyr ${ }^{147}$ in Irenaeus, ${ }^{148}$ in 1 Peter $^{149}$ and in Ephesians. ${ }^{150}$ Secondly, this dogma is founded on a pre-Christian myth of a battle between the powers of Heaven and Hell. $^{151}$ It is applied to personified Wisdom, in the Wisdom of Jesus the Son of Sirach. ${ }^{152}$ There is therefore no occasion for surprise in finding it in an undeveloped form in the Odes. It was later applied not only to Jesus but to the Mandaean Saviour. ${ }^{153}$ This would again indicate some connection of the doctrine with the Johannites, and, as a matter of fact, early legend sent John to Hädes ${ }^{154}$ as the precursor of Jesus. It is remarkable that the connection already seems to have been made by the author of I Peter ${ }^{155}$

1s 1 Peter i. 11.

${ }^{140}$ On the relation of this gospel to the Ephesian Fourth Gospel, cf. Erbes in Zeitschrift $f$. Kirchengesch., XXXIII, 234ff.

${ }^{147}$ Dialogue, Chap. 72.

is Adv. Haer., IV, 27.

160 iii. 18 ff.

150 iv. 19.

${ }^{102}$ W. Bousset, Kyrios Christos, 1913, p. 38.

${ }^{202}$ In the Latin translation of xxiv. 32. This may be a Christian interpolation, but is not necessarily so, says Bousset, p. 34 .

${ }^{13 s}$ Bousset, 38.

${ }^{164}$ Hippolytus, Christ and Antichrist, Chap. 45; Origen, Hom. IV in Luc., ed. Lommatsch, V, 99; Tract. Orig., ed. Batiffol, 155; Descensus, II, 2.

${ }^{130}$ iii. $18 \mathrm{ff}$. 
who places the descensus in close proximity to remarks about baptism:

"Because Christ also suffered for sins once, the righteous for the unrighteous, that he might bring us to God, being put to death in the flesh, but quickened in the spirit; in which also he went and preached unto the spirits in prison which aforetime were disobedient, when the longsuffering of God waited in the days of Noah, while the ark was a preparing, wherein few, that is, eight souls, were saved through water: which also after a true likeness doth now save you, even baptism."

It is plain to me that the author of the lines had in mind some source very like that used by Ode XLII. At any rate the date should decide the question. If the Odes were really written in the middle of the first century they cannot be dependent on legends of the second century, though these may well be dependent on them.

A last word may be devoted to the author's person. The only possible name to suggest is that of Apollos, and we know too little of him to say definitely whether he wrote the Odes or not. His Alexandrian extraction would rather speak in his favor, for his reliance on $\mathrm{Philo}^{\mathrm{s} 5}$ and Wisdom and the Hermetic literature has already been noted. His career also, as far as we know it, begins and ends at Ephesus, and he is of the right date. It is remarkable that B. W. Bacon has traced his influence in the thought of the Fourth Gospel: "We have no means of proving," says he, "that Apollos ever touched pen to paper; yet it is permissible to say that if any identifiable spirit speaks through the Fourth Gospel besides that of Paul it is such a spirit as that of Apollos. ${ }^{157}$ It is just possible

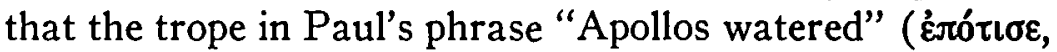
I Cor. iii. 6) was suggested to him by that missionary's

180 "The Odes and Philo," J. T. Marshall, Expositor, 1911, I, 385ff, 519ff.

${ }^{187}$ The Fourth Gospel in Research and Debate, 1909, p. 283. 
THE DISCIPLES OF JOHN AND THE ODES OF SOLOMON. I 99

addiction to the said element, but no safe inference as to his authorship can be drawn from that. If Apollos was a Jew by birth, and the author of the Odes a Gentile, they could not have been the same person, but neither of these suppositions is beyond doubt. Perhaps the weightiest argument against Apollos's authorship is that we have no clearer indication in favor of it.

Preserved Smith.

Pough keepsie, N. Y. 